\title{
Limbic encephalitis with NMDA receptor antibodies
}

INSERM

\section{Source}

INSERM. (1999). Orphanet: an online rare disease and orphan drug data base. Limbic encephalitis with NMDA receptor antibodies. ORPHA:217253

Limbic encephalitis with anti-N-methyl-D-aspartate (NMDA) receptor antibodies is a recently described type of encephalitis (see this term) affecting young women with teratoma of ovary (see this term) and associated with antibodies that react with neuronal cell surface auto-antigens. 